\title{
Digestion of $\alpha$-Lactalbumin in Rat Gastrointestinal Tracts
}

\author{
Tohru Fushiki, Nami Yamamoto, Ichiro NAEShiRo \\ and Kazuo IwaI* \\ Laboratory of Nutritional Chemistry, Department of Food Science \\ and Technology, Faculty of Agriculture, Kyoto University, \\ Sakyo-ku, Kyoto 606, Japan
}

Received June 20, 1985

\begin{abstract}
The digestion process for $\alpha$-lactalbumin was investigated and compared with that of ovalbumin using their antigenicity as an index. $\alpha$-Lactalbumin did not lose its antigenicity by incubation even at high temperature or acidic $\mathrm{pH}$ levels. By measuring the residual antigen, $\alpha$ lactalbumin is shown to be hydrolysed rapidly by pepsin $(1: 66)$ or pancreatin $(1: 25)$ in vitro without any previous denaturation treatment. The $\alpha$-lactalbumin antigen also rapidly disappeared in the gastrointestinal tracts of rats. One hour after administering $250 \mathrm{mg}$ of whey protein which contained $42 \mathrm{mg}$ of the $\alpha$-lactalbumin antigen, the $\alpha$-lactalbumin antigen remaining in the stomach was only $3.95 \pm 0.4 \mathrm{mg}$. In the small intestine, a trace amount of the antigen was detected. In more distal parts of the tract, no antigen was found. Rapid gastric emptying was achieved by using $\alpha$ lactalbumin in a $0.9 \% \mathrm{NaCl}$ solution without carbohydrate and lipids. However, the antigen recovered from the small intestine remained at a trace level. Thus the capacity for $\alpha$-lactalbumin digestion in the small intestine may be very large. In the previous examination, a significant amount of the intact ovalbumin antigen was detected in the stomach and small intestine. These results suggest that the digestion of $\alpha$-lactalbumin measured by the disappearance of its antigen is significantly different from ovalbumin digestion.
\end{abstract}

Nixon et al. ${ }^{1,2)}$ and some other investigators $^{3)}$ have reported that dietary protein was rapidly digested in the duodenum or proximal small intestine of men. On the other hand, Curtis and $\mathrm{Kim}^{4)}$ indicated that the most part of administered protein, which was the soluble fraction of rat liver randomly labeled with $\left[{ }^{14} \mathrm{C}\right]$ amino acids, was digested and absorbed in the middle or distal part of the small intestine in rats. Adibi et al. $^{5)}$ detected intact BSA in human ileum with analytical electrophoresis, and similar observations have been reported by Pang et al. ${ }^{6)}$ and OchoaSolano et al. ${ }^{7,8)}$ with $\left[{ }^{125} \mathrm{I}\right] \mathrm{BSA}$ and $\left[{ }^{75} \mathrm{Se}\right]-$ ovalbumin, respectively.

Dietary proteins have such individual properties as solubility, resistance to denaturation and affinity to proteases. To explain the inconsistency in previous results, a new method was needed that could measure the digestion of food proteins as distinct from endogenous proteins. The present authors have recently reported that the disappearance of antigenicity of food protein may be a useful index of digestion. $^{9)}$

The present study investigated the digestion process for $\alpha$-lactalbumin by using its antigenicity as an index of digestion, and the behavior of $\alpha$-lactalbumin in the gastrointestinal tracts was compared with that of ovalbumin.

\section{MATERIALS AND METHODS}

Materials. $\alpha$-Lactalbumin (grade II) and ovalbumin (grade VI) were obtained from Sigma Chemical Co., pepsin $(35,000$ units/g) was from Merck, pancreatin NF and Freund's complete adjuvant were from Difco Laboratories. CNBr-activated Sepharose 4B was from

* To whom all correspondence should be addressed.

Abbreviations: TLCK, $p$-tosyl-L-lysine chloromethyl ketone; TPCK, $p$-tosyl-L-phenylalanine chloromethyl ketone. 
Pharmacia Fine Chemicals. Casein, sucrose, mineral mixture, and the stock diets MF and RC 4 were purchased from Oriental Yeast Co., Ltd. (Tokyo, Japan). Whey protein was supplied from Otsuka Shokuhin Co., Ltd. (Osaka, Japan), this being freeze-dried whey protein containing $16.8 \%$ of $\alpha$-lactalbumin. Agarose A-37, $p$-tosyl-Lphenylalanine chloromethyl ketone (TPCK), p-tosyl-Llysine chloromethyl ketone (TLCK) and other reagents were obtained from Nakarai Chemicals Ltd. (Kyoto, Japan).

In vitro experiments. Most of the methods for the in vitro and in vivo experiments were the same as those detailed in the previous paper. ${ }^{9)}$ Heat or acid treatment, and pepsin or pancreatin digestion of the $\alpha$-lactalbumin were carried out and compared with the previously obtained results regarding ovalbumin.

Digestion of $\alpha$-lactalbumin in vivo. Male albino rats of the Wistar strain $(130 \sim 175 \mathrm{~g})$ were fasted between 9:00 and 17:00, and force-fed with $2 \mathrm{ml}$ of standard meal (Table I) at 17:00. The rats were killed by decapitation at 0.5 and $1 \mathrm{hr}$ after feeding, and the contents of the stomach, proximal, middle and distal parts of the small intestine, cecum and colon were washed out with $10 \mathrm{ml}$ of $0.05 \mathrm{M}$ sodium phosphate buffer at $\mathrm{pH} 7.2$ which contained $0.9 \%$ $\mathrm{NaCl}$ and $0.05 \%$ protease inhibitors (TPCK and TLCK). The samples were immediately frozon by liquid nitrogen and stored until use for an assay below $-30^{\circ} \mathrm{C}$.

The $\alpha$-lactalbumin antigen in each sample was measured by the single immunodiffusion technique. ${ }^{10}$ ) For the second experiment, the rats were fed with $2 \mathrm{ml}$ of whey solution $(125 \mathrm{mg}$ protein $/ \mathrm{ml})$ in physiological saline including phenol red, and were killed at 0.5 and $1.0 \mathrm{hr}$ after administration. In this experiment, gastric emptying was calculated by the percentage of phenol red remaining in the stomach. The detailed conditions were described in the previous paper. ${ }^{9)}$

$H P L C$ analysis of the immuno-reactive, non-precipitative antigen fraction from an insoluble $\alpha$-tactalbumin antibody column. The globulin fraction of the $\alpha$-lactalbumin antiserum was prepared by the salting-out technique. The dialyzed globulin fraction ( $50 \mathrm{mg}$ of protein) was absorbed by $2 \mathrm{ml}$ of CNBr-activated Sepharose 4B. HPLC analysis of peptides with or without absorption by an insolubilized $\alpha$-lactalbumin antibody column was carried out on Waters HPLC equipment with a micro-Bondapak C-18 column and Bio-Rad C-4 column. A programmed gradient solvent system $\left(0.05 \%\right.$ tri-fluoro acetic acid- $\mathrm{CH}_{3} \mathrm{CN}$, or $0.1 \%$ phosphate- $\mathrm{CH}_{3} \mathrm{CN}$ ) was used.

Preparation of $\alpha$-lactalbumin antiserum. Five $\mathrm{mg}$ of $\alpha$ lactalbumin in $0.5 \mathrm{ml}$ of saline was emulsified with $0.5 \mathrm{ml}$ of Freund's complete adjuvant, and the emulsion was subcutaneously injected into a rabbit. The rabbit was boosted with $5 \mathrm{mg}$ of $\alpha$-lactalbumin solution without the adjuvant after 4 weeks. The rabbit was fed on a com-
TABLE I. DiET COMPOSITION

\begin{tabular}{lcc}
\hline \multicolumn{1}{c}{ Ingredient } & Diet I $^{a}$ & ${\text { Diet } \text { II }^{b}}^{c}$ \\
\hline Whey protein $^{c}$ & $250 \mathrm{mg}$ & $250 \mathrm{mg}$ \\
Sucrose & 275 & 0 \\
Soluble starch & 552 & 0 \\
Mineral mixture $^{d}$ & 48 & 0 \\
Soybean oil $^{\prime}$ & $75 \mu \mathrm{l}$ & 0 \\
\hline
\end{tabular}

a Diet I was filled up to $2 \mathrm{ml}$ with distilled water containing phenol red.

$b$ Diet II was filled up to $2 \mathrm{ml}$ with $0.9 \% \mathrm{NaCl}$ solution containing phenol red.

c $250 \mathrm{mg}$ of whey protein contained $42 \mathrm{mg}$ of $\alpha$ lactalbumin.

d The mineral mixture (Oriental Yeast Co., Japan) had the following composition $(\mathrm{g} / 100 \mathrm{~g}$ of mixture): $\mathrm{CaHPO}_{4} \cdot 2 \mathrm{H}_{2} \mathrm{O}, 14.56 ; \mathrm{KH}_{2} \mathrm{PO}_{4} ; 25.72 ; \mathrm{NaH}_{2} \mathrm{PO}_{4}$, 9.35; NaCl, 4.66; Ca-lactate, 35.09; Fe-citrate, 3.18; $\mathrm{MgSO}_{4}, 7.17 ; \mathrm{ZnCO}_{3}, 0.11 ; \mathrm{MnSO}_{4} \cdot 4 \mathrm{H}_{2} \mathrm{O}, 0.12$; $\mathrm{CuSO}_{4} \cdot 5 \mathrm{H}_{2} \mathrm{O}, 0.03 ; \mathrm{KI}, 0.01$.

mercial diet ad libitum, and was bled 10 days after the booster shot. Ovalbumin antibody had previously been prepared and stored at $-80^{\circ} \mathrm{C}$ in our laboratory.

\section{RESULTS}

\section{Properties of $\alpha$-lactalbumin antigenicity}

One $\mathrm{mg} / \mathrm{ml}$ of $\alpha$-lactalbumin was incubated in $0.1 \mathrm{M}$ sodium acetate buffer of $\mathrm{pH} 0.5 \sim 3.0$ at $37^{\circ} \mathrm{C}$ for $2 \mathrm{hr}$, or $2.0 \mathrm{mg} / \mathrm{ml}$ of $\alpha$-lactalbumin was maintained at each temperature $(30$ $90^{\circ} \mathrm{C}$ ) for $10 \mathrm{~min}$ at $\mathrm{pH} 10$. As shown in Fig. 1 , the $\alpha$-lactalbumin lost none of its antigenicity under these conditions, but when $\alpha$ lactalbumin was incubated at $\mathrm{pH} 7.2$ in a boiling water bath, $80 \%$ of the antigen had disappeared after $1 \mathrm{hr}$ and $100 \%$ after $2 \mathrm{hr}$. The residual antigen after boiling was identical with the native one. Partially denatured antigen which retained some antigenicity was not detected (data not shown).

\section{Digestion of $\alpha$-lactalbumin in vitro}

$\alpha$-Lactalbumin rapidly lost its antigenicity by pepsin digestion at $\mathrm{pH} 1.5$ as shown in Fig. 2. However, without pepsin digestion, the $\alpha$ lactalbumin antigen did not decrease even at pH 1.5 .

Pepsin digested at $\mathrm{pH} 1.5$ for $30 \mathrm{~min}$ gave a spur against the intact $\alpha$-lactalbumin with 

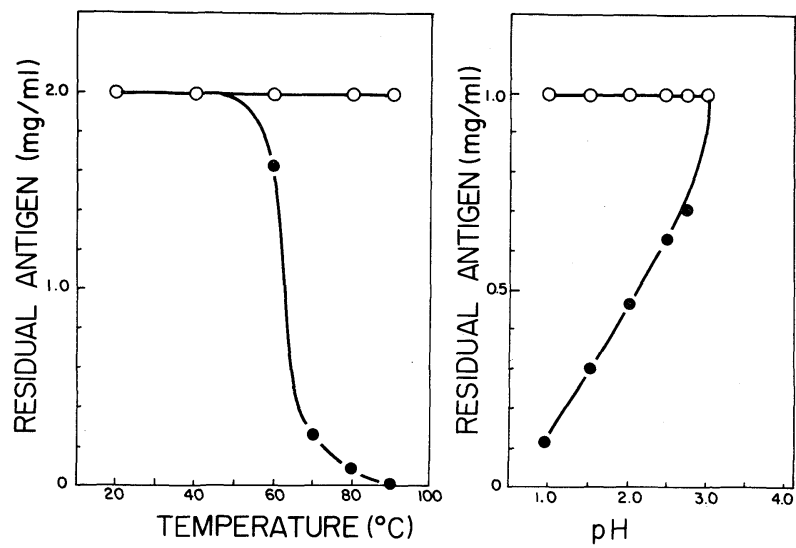

Fig. 1. Acid and Heat Denaturation of $\alpha$-Lactalbumin and Ovalbumin.

Two $\mathrm{mg} / \mathrm{ml}$ of $\alpha$-lactalbumin (O) or ovalbumin (O) solution at $\mathrm{pH} 10$ was maintained at each temperature for $10 \mathrm{~min}$ (left). One $\mathrm{mg} / \mathrm{ml}$ of $\alpha$-lactalbumin or ovalbumin was incubated in a sodium acetate- $\mathrm{HCl}$ buffer at the indicated $\mathrm{pH}$ at $37^{\circ} \mathrm{C}$ for $2 \mathrm{hr}$. Immediately after incubation, the $\mathrm{pH}$ level of the mixture was adjusted to 7.2 by adding $0.5 \mathrm{M}$ potassium phosphate buffer at $\mathrm{pH} 7.2$ (right). The $\alpha$-lactalbumin antigen or ovalbumin antigen was determined by single immunodiffusion and is expressed as a percentage of the starting value.

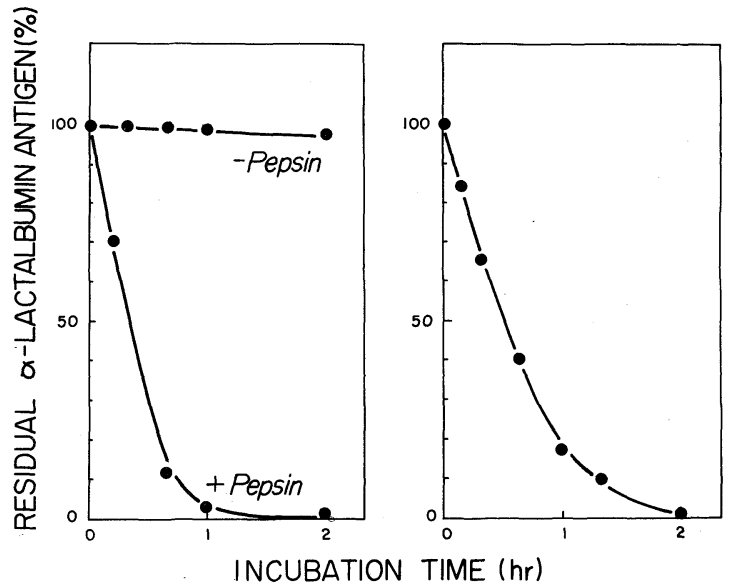

FIG. 2. Pepsin and Pancreatin Digestion of $\alpha$-Lactalbumin.

$\alpha$-Lactalbumin $\left(50 \mathrm{mg}\right.$ ) was incubated with or without $0.75 \mathrm{mg}$ of pepsin at $37^{\circ} \mathrm{C}$ in $7.5 \mathrm{ml}$. The pH level was adjusted to 1.5 by $\mathrm{HCl}$ (left). Pancreatin digestion was carried out by incubating $50 \mathrm{mg}$ of each protein with $2 \mathrm{mg}$ of pancreatin $\mathrm{NF}$ in $10 \mathrm{ml}$ of $0.05 \mathrm{M}$ potassium phosphate buffer at $\mathrm{pH} 8.0$ and $37^{\circ} \mathrm{C}$ (right). The $\alpha$ lactalbumin antigen was determined by single immunodiffusion.

double immunodiffusion, but $\alpha$-lactalbumin thoroughly digested with pepsin lost its antigenicity completely and the spur disappeared (data not shown). In pancreatin digestion, the partially digested antigen was not detectd, and the resulting residual antigen was identical with the intact one. Pancreatin digestion made $\alpha$-lactalbumin gradually lose its antigenicity.
After $1 \mathrm{hr}$ of digestion, the residual antigen was about $18 \%$ against the original $\alpha$-lactalbumin materials, as shown in Fig. 2.

To examine whether an immuno-reactive, non-precipitative antigen fragment of $\alpha$-lactalbumin was produced or not in the gastrointestinal tracts, pepsin and pancreatin digests and the soluble fraction of the small intestinal 
contents were passed through an insolubilized $\alpha$-lactalbumin antibody column. The digests with or without absorption by the column were measured for their peptide pattern by HPLC. No difference with or without absorption could be detected under our experimental conditions (data not shown). Thus, immuno-reactive, non-precipitative peptide may not accumulate in the gastrointestinal tracts.

\section{$\alpha$-Lactalbumin digestion in vivo}

Rats were force-fed on a diet containing $42 \mathrm{ml}$ of $\alpha$-lactalbumin (Table I). One hr after feeding, less than $10 \%$ of the administered $\alpha$ lactalbumin antigen was detected in the small intestine (Table II). According to the observation in vitro, $\alpha$-lactalbumin was well digested by pepsin, which suggests that the residence time for $\alpha$-lactalbumin in the stomach influences the overall digestion of the $\alpha$ lactalbumin molecule. To reveal the contribution to digestion of the stomach and the capacity of the small intestine, the authors tried accelerating the gastric emptying of $\alpha$ lactalbumin. As shown in Fig. 3, when $250 \mathrm{mg}$ of whey protein in $0.9 \% \mathrm{NaCl}$ solution was administered without carbohydrate or lipids (diet II), the phenol red remaining in the stomach that was the marker for gastric emptying was only $27.5 \pm 6.3 \%$ at $30 \mathrm{~min}$ after feeding against $75.5 \pm 5.3 \%$ with the standard diet (diet I). Table III indicates that the $\alpha$-lactalbumin antigen was scarcely detected in the small intestinal contents both at $30 \mathrm{~min}$ and at $1 \mathrm{hr}$, despite of its quick transfer into the small intestine by rapid gastric emptying.

\section{DISCUSSION}

In the present study, the differences between $\alpha$-lactalbumin and ovalbumin in their properties of antigenic determinants and digestibility were observed and compared with previous data. ${ }^{9)}$ The antigenic determinants of $\alpha$-lactalbumin were hardly diminished by heat or acid treatment, although those of ovalbumin were
TABle II. Residual $\alpha$-LaCtalbumin Antigen IN THE Gastrointestinal Tracts With THE Standard Diet (Diet I)

\begin{tabular}{lcc}
\hline \multirow{2}{*}{ Organ } & \multicolumn{2}{c}{$\alpha$-Lactalbumin antigen $(\mu \mathrm{g})$} \\
\cline { 2 - 3 } & $30 \mathrm{~min}$ & $1 \mathrm{hr}$ \\
\hline Stomach & $7410 \pm 380$ & $3950 \pm 490$ \\
Small intestine & & \\
Proximal & $1.3 \pm 1.1$ & $6.7 \pm 3.3$ \\
Middle & ND & $19.1 \pm 14$ \\
Distal & ND & ND \\
Cecum & ND & ND \\
Colon & ND & ND \\
\hline
\end{tabular}

Values are means $\pm \operatorname{SEM}(n=4$ or 5$)$. ND, not detected by the present assay.

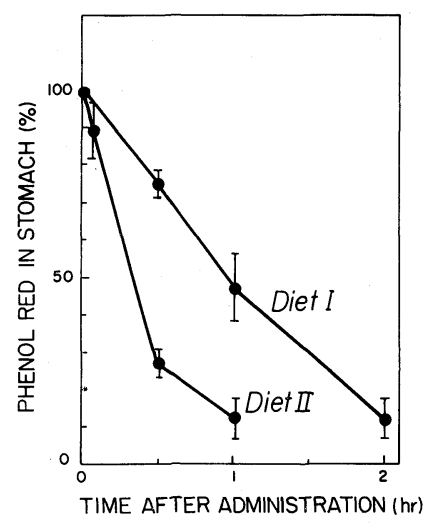

FIG. 3. Gastric Emptying of Diets I and II.

The composition of diet $\mathrm{I}$ is described in Table I. Phenol red content in stomach was determined by the method previously reported and is expressed as a percentage of the amount administered.

TABle III. Residual $\alpha$-Lactalbumin Antigen in the Gastrointestinal Tracts by Administration of CARbohydrate- AND LIPID-FREE DIET (Diet II)

\begin{tabular}{lcc}
\hline \multirow{2}{*}{ Organ } & \multicolumn{2}{c}{$\alpha$-Lactalbumin antigen $(\mu \mathrm{g})$} \\
\cline { 2 - 3 } & $30 \mathrm{~min}$ & $1 \mathrm{hr}$ \\
\hline Stomach & $950 \pm 140$ & $51.5 \pm 17$ \\
Small intestine & & \\
Proximal & $15.0 \pm 9.0$ & $4.8 \pm 4.0$ \\
Middle & $50.6 \pm 1.3$ & $4.0 \pm 2.0$ \\
Distal & $7.5 \pm 6.5$ & ND \\
Cecum & ND & ND \\
Colon & ND & ND \\
\hline
\end{tabular}

Values are means $\pm \operatorname{SEM}(n=4$ or 5$) . \mathrm{ND}$, not detected. 
highly sensitive to its conformational changes and were all destroyed at once by these denaturation processes. ${ }^{9)}$ Pepsin- or pancreatindigested $\alpha$-lactalbumin made a spur against the intact one by double immunodiffusion indicating that the partially digested antigen partially reacted with the antiserum. Thus, strictly speaking, we did not exactly determine the antigen contents of the pepsin digests. However, the appearance of the breakdown antigen was only in the initial stages, and our observed spur in the double immunodiffusion assay was very slight. It can thus be said that the $\alpha$-lactalbumin assay used in the present examination was satisfactory. The immunoreactive, non-precipitative breakdown-product of $\alpha$-lactalbumin, the monovalent antigen for example, was not detected by an immunoabsorbent column and HPLC analysis. The nonprecipitative antigen was not found in the lumen, and it did not interfere with measurement of the $\alpha$-lactalbumin antigen in the luminal contents.

The $\alpha$-lactalbumin antigen rapidly disappeared with both pepsin and pancreatin digestion, while the ovalbumin antigen has been reported to be hardly digested by pepsin or pancreatin if they had not previously been denatured. ${ }^{9)}$ Although acid- or heat-treated $\alpha$ lactalbumin showed slightly better digestibility than the native one (unpublished data), denaturation was not indispensable for the digestion. This is similar to that of casein, in which pepsin or pancreatin digestibility is not affected by heat or acid treatment. It also indicates that the disappearance of the $\alpha$-lactalbumin antigen during digestion implies enzymic hydrolysis, while that of ovalbumin implies denaturation, which may precede hydrolysis in the stomach or may occur by the attack of a large excess of protease in the small intestine. Rapid TCA-soluble peptide production was observed almost concurrently with the intact antigen disappearance in vitro. Thus, the disappearance of the protein antigens substantiates the rate-limiting of overall digestion in vitro and probably in vivo. These findings support our proposal that the disappearance of the protein antigen is an appropriate and meaningful index for digestion.

In spite of the acid resistance of $\alpha$-lactalbumin, its antigen remained less than that of ovalbumin in the rat stomach (Fig. 1, Table II). This is inconsistent with the result of pepsin digestion in vitro. The $\alpha$-lactalbumin we used contained about $0.3 \mathrm{~mol}$ of $\mathrm{Ca}$ per molecule. The digestibility of $\alpha$-lactalbumin under the conditions tested was not affected significantly by the presence or absence of $\mathrm{Ca}$ (unpublished data). Its antigen was scarcely detected in the small intestinal contents, even under the conditions of rapid gastric emptying, and the capacity for $\alpha$-lactalbumin digestion in the stomach and proximal small intestine may be significantly large. Almost all the $\alpha$-lactalbumin would be digested at the initial stage of gastrointestinal digestion. Sklan ${ }^{11)}$ has observed that the normal digestion and absorption capacity of the chick duodenum for casein was exceeded by an experiment with a $10 \%$ to $45 \%$ casein diet administration, while a significant quantity of ovalbumin has been transfered into the duodenum without denaturation or digestion by the stomach and then accumulated in the small intestine. ${ }^{9)}$ Similar differences of digestion have been observed with casein, gelatin and zein by Chen et al., ${ }^{12)}$ and with casein, zein, gliadin, gelatin, soybean and egg albumin by Rogers et al. ${ }^{13)}$ Recently, Sklan and Hurwitz ${ }^{14)}$ distinguished the behavior in digestion of casein from that of soybean protein in the chick lumen. They suggested that during protein absorption from a soybean meal diet, solubilization and the breakdown of intermediate peptide were rate-limiting; on the other hand, when casein was fed, the rate of uptake of low molecular weight peptide appeared to be limiting. In these previous investigations, they measured the nitrogen, amino acid and protein contents in the lumen with endogenous proteins. Therefore, their data were derived from the sum of the administered protein and endogenous proteins. The present method has shown the advantage that it can specifically detect the food protein in digests. The present results proved directly the 
diversity in the digestion processes of different food proteins by using a new index.

Acknowledgment. This work was supported in part by a Grant-in-Aid (to K. I.) for Scientific Research (No. 56860026) from the Ministry of Education, Science and Culture of Japan.

\section{REFERENCES}

1) S. E. Nixon and G. E. Mawer, Br. J. Nutr., 24, 227 (1970).

2) S. E. Nixon and G. E. Mawer, Br. J. Nutr., 24, 241 (1970).

3) B. Borgstrom, A. Dahlqvist, G. Lundh and J. Sjovall, J. Clin. Invest., 36, 1521 (1957).

4) K. J. Curtis, Y. S. Kim, J. M. Perdomo, D. B. A. Silk and J. S. Whitehead, J. Physiol., 274, 409 (1978).

5) S. A. Adibi and D. W. Mercer, J. Clin. Invest., 52,
1586 (1973).

6) K. Y. Pang, W. A. Walker and K. J. Bloch, Gut, 22, 1018 (1981).

7) A. Ochoa-Solano and C. Gitler, J. Nutr., 94, 249 (1968).

8) A. Ochoa-Solano and C. Gitler, J. Nutr., 94, 243 (1968).

9) T. Fushiki, N. Yamamoto and K. Iwai, Agric. Biol. Chem., 49, 1335 (1985).

10) J. S. Garvey, N. E. Cremer and D. H. Sussdorf, Methods in Immunology, third edition p. 313, W. A. Benjamin, Inc., Massachusetts.

11) D. Sklan, J. Nutr., 110, 989 (1980).

12) M.-L. Chen, Q. R. Rogers and A. E. Harper, J. Nutr., 76, 235 (1962).

13) Q. R. Rogers, M.-L. Chen, C. Peraino and A. E. Harper, J. Nutr., 72, 331 (1960).

14) D. Sklan and S. Hurwitz, J. Nutr., 110, 139 (1980). 